\title{
High-flow nasal cannula oxygen therapy in children: a clinical review
}

Ji-Won Kwon, MD, PhD

Department of Pediatrics, Seoul National University Bundang Hospital, Seongnam, Korea

High-flow nasal cannula (HFNC) is a relatively safe and effective noninvasive ventilation method that was recently accepted as a treatment option for acute respiratory support before endotracheal intubation or invasive ventilation. The action mechanism of HFNC includes a decrease in nasopharyngeal resistance, washout of dead space, reduction in inflow of ambient air, and an increase in airway pressure. In preterm infants, HFNC can be used to prevent reintubation and initial noninvasive respiratory support after birth. In children, flow level adjustments are crucial considering their maximal efficacy and complications. Randomized controlled studies suggest that HFNC can be used in cases of moderate to severe bronchiolitis upon initial low-flow oxygen failure. HFNC can also reduce intubation and mechanical ventilation in children with respiratory failure. Several observational studies have shown that HFNC can be beneficial in acute asthma and other respiratory distress. Multicenter randomized studies are warranted to determine the feasibility and adherence of HFNC and continuous positive airway pressure in pediatric intensive care units. The development of clinical guidelines for HFNC, including flow settings, indications, and contraindications, device management, efficacy identification, and safety issues are needed, particularly in children.

Key words: High-flow nasal cannula, Noninvasive ventilation, Pediatric indication, Child

\section{Introduction}

Since its introduction as an alternative to continuous positive airway pressure (CPAP) in preterm infants, high-flow nasal cannula (HFNC) oxygenation has been widely used for various respiratory conditions in adults and neonates. ${ }^{1,2)}$ Because of its easy application, effectiveness, and relatively good safety, HFNC is considered an essential intensive care device. Indications for HFNC in preterm infants include initial noninvasive respiratory support (NRS) after birth and the prevention of reintubation. Despite broader indications in adults, the efficacy of HFNC in children has been demonstrated limitedly after the first use in acute bronchiolitis. This review focuses on indications, flow settings, responder evaluation, and safety of HFNC in children.

\section{Current understanding of action mechanism}

The full name of HFNC is heated humidified HFNC oxygen therapy. Adjustable $\left(\mathrm{FiO}_{2} 21 \%-100 \%\right)$ heated $\left(34^{\circ} \mathrm{C}-37^{\circ} \mathrm{C}\right)$ oxygen with nearly $100 \%$ relative humidity can avoid mucosal injury and patient discomfort from cold, dry air. Heated humidification can encourage the clearance of secretions and reduce bronchoconstriction. The basic principle of HFNC is to set a higher oxygen flow than inspiratory demand flow according to the clinical situation. This can lead washout of the upper airways, decreased nasal resistance, and reduced dead space. ${ }^{3)}$ Current studies revealed that HFNC induces positive airway pressure to lead alveolar recruitment of collapsed lesions and the elevation of functional residual capacity. ${ }^{4,5}$ Additionally, HFNC reduces the inflow of ambient air, minimizes the dilution of wanted gas composition, and improves oxygenation. $\left.{ }^{6}\right)$ There is no age-dependent differentiation between adults and children in its mechanism of action.

\section{Flow setting and cannula size for pediatric patients}

The aforementioned principle, a higher flow setting than inspiratory demand, can be applied to patients of all ages. Airway pressure generated from a high-flow system varies and depends on flow amount, cannula and nares sizes, and degree of mouth opening in an experimental study. In the experimental setting, positive lung-distending pressure increased as the flow increased from 0 to $12 \mathrm{~L} / \mathrm{min}^{8}{ }^{8)}$ Recent studies reported that limited pressure delivery of $2-4 \mathrm{cmH}_{2} \mathrm{O}$ was measured in the pharynx and esophagus in children and adults with HFNC. ${ }^{9-11)}$

There is a lack of guidance about optimal flow in pediatric patients. Important randomized controlled studies conducted in patients with acute bronchiolitis provided information about

Corresponding author: Ji-Won Kwon, MD, PhD. Department of Pediatrics, Seoul National University Bundang Hospital, 82 Gumi-ro 173 beon-gil, Bundang-gu, Seongnam 13620, Korea 
appropriate flow. ${ }^{12-14)}$ Patients younger than 24 months of age tolerated the flow of $1-2 \mathrm{~L} / \mathrm{kg} / \mathrm{min}$ (up to $20 \mathrm{~L} / \mathrm{min}$ ) and $3 \mathrm{~L} / \mathrm{kg}$ / $\min$. However, patients were uncomfortable with $3 \mathrm{~L} / \mathrm{kg} / \mathrm{min}$ despite the same efficacy. ${ }^{14)}$ Considering the flow limitation in adults $(50-60 \mathrm{~L} / \mathrm{min})$, the reasonable flow rate is thought to be $1-2 \mathrm{~L} / \mathrm{kg} / \mathrm{min}$ up to $10 \mathrm{~kg}$ in patients, followed by an increase of $0.5 \mathrm{~L} / \mathrm{kg} / \mathrm{min}$. One study comparing the efficacy of HFNC and CPAP noted no differences in length of stay in the intensive care unit (ICU) and the need for mechanical ventilation between $2 \mathrm{~L} / \mathrm{kg} / \mathrm{min}$ of HFNC and $7 \mathrm{cmH}_{2} \mathrm{O}$ of CPAP. ${ }^{15)}$ Interestingly, there was a large variation of maximal flow rates $(\mathrm{L} / \mathrm{min})$ in the different age groups among 67 hospitals. ${ }^{16)}$ These results showed the importance of comprehensive understanding of the mechanism and optimal flow to ensure better outcomes.

Cannula size varies by age and body weight. Manufacturers recommend that the cross-sectional area of the cannula be no more than $50 \%$ that of the nares because of the risk of unexpected elevations in airway pressure and the following risk of air leak. That means that the appropriate outer diameter of the cannula is no more than two-thirds that of the nares. Recommended flow settings and cannula sizes for pediatric patients are summarized in Table 1.

\section{Indications for HFNC in children}

During recent decades, HFNC has been widely used in adult patients. Indications from the evidence in adults include acute hypoxemic respiratory failure, postextubation support, preoxygenation before intubation or during bronchoscopy, postoperative respiratory failure, and acute pulmonary edema. ${ }^{17)}$ Many pediatric studies have included patients with acute bronchiolitis. However, other indications have been studied, including asthma, sleep apnea, pneumonia, transport of a critical patient, and postextubation respiratory support. ${ }^{17,18)}$

We should know that contraindications for HFNC include upper airway abnormalities that may make HFNC ineffective or potentially dangerous, life-threatening hypoxia, hemodynamic instability, facial bone or skull base trauma, and pneumothorax. In addition, HFNC should be applied carefully in patients with a decreased level of consciousness, congenital heart disease, acute asthma, or chronic respiratory failure. The recent pediatric studies are summarized in Table 2.

\section{Acute bronchiolitis}

Acute bronchiolitis has been the main indication for HFNC in patients older than neonates. Recent studies confirmed the effectiveness of HFNC as rescue therapy in the treatment of moderate to severe bronchiolitis. The first randomized controlled trial (RCT) included 202 patients younger than 24 months with moderate bronchiolitis. ${ }^{12)} \mathrm{HFNC}$ of $1 \mathrm{~L} / \mathrm{min} / \mathrm{kg}$ with a fraction of inspired oxygen $\left(\mathrm{FiO}_{2}\right)$ of 0.6 was compared with standard low flow $(2 \mathrm{~L} / \mathrm{min})$. There were no differences in time on oxygen treatment and transfer rate to the ICU, but a lower treatment failure rate was found in the HFNC group. Another large-scale RCT of 1,472 infants $<12$ months of age with bronchiolitis confirmed the significantly lower treatment failure rate in the HFNC group than in the standard oxygen group. ${ }^{13)}$ There were no differences in duration of hospital stay, duration of oxygen therapy, or ICU admission. These 2 remarkable RCTs concluded that HFNC plays a role in rescue therapy for patients with moderate to severe bronchiolitis and stated that physicians should remember that the first use of HFNC does not modify the disease process. In a recent systematic review of $9 \mathrm{RCTs},{ }^{19)}$ there were no differences in length of stay, duration of oxygen therapy, ICU transfer, intubation rate, respiratory rate (RR), $\mathrm{SpO}_{2}$, or adverse events in the HFNC versus standard oxygen therapy and nasal CPAP groups. The incidence of treatment failure in the HFNC group was lower than that of the standard oxygen group but higher than that of the nasal CPAP group.

\section{Asthma}

Limited data support the use of HFNC in children with conditions other than bronchiolitis. However, more clinical evidence is expected soon because HFNC is easily applied with a broad indication in adults and a definite advantage in children with bronchiolitis.

A retrospective observational study conducted in patients with status asthmaticus $(\mathrm{N}=73)$ reported improvements in $\mathrm{pH}, \mathrm{pCO}_{2}$, heart rate (HR), $\mathrm{RR}$, and oxygenation in the HFNC group compared to the standard oxygen group. ${ }^{20)}$ Two treatment failures occurred in the HFNC group $(n=39)$ : one pneumothorax and one case of other noninvasive support. Another

Table 1. Recommended flow settings and cannula sizes for high-flow nasal cannula therapy in pediatric patients

\begin{tabular}{|c|c|c|c|c|}
\hline \multirow{2}{*}{ Age } & \multirow{2}{*}{ Body weight (kg) } & \multirow{2}{*}{ Flow range $(\mathrm{L} / \mathrm{min})^{\mathrm{a})}$} & \multicolumn{2}{|c|}{ Manufacturer-recommended cannula size } \\
\hline & & & Fischer \& Paykel ${ }^{\text {b) }}$ & Vapotherm \\
\hline$\leq 1$ Month & $<4$ & $5-8$ & $\mathrm{~S}, \mathrm{M}$ & Neonatal, infant \\
\hline 1 Month-1 year & 4-10 & $8-20$ & $M, L$ & Pediatric small \\
\hline 1-6 Years & $10-20$ & $12-25$ & $L, X L$ & Pediatric small, pediatric (adult small) \\
\hline $6-12$ Years & $20-40$ & $20-30$ & $\mathrm{XL}$, small & Pediatric (adult small), \\
\hline $12-18$ Years & $>40 \mathrm{~kg}$ & $25-50$ & Small, medium & Pediatric (adult small), adult \\
\hline
\end{tabular}

$\mathrm{OD}$, outer diameter.

a) Allowed flow range might differ from the manufacturer's recommendations. ${ }^{\text {b) }} \mathrm{XS}, \mathrm{S}, \mathrm{M}, \mathrm{L}$, and XL Optiflow Junior 2; Small and Medium Optiflow Plus. 
Table 2. Clinical indications for high-flow nasal cannula therapy in pediatric patients

\begin{tabular}{|c|c|c|c|c|}
\hline $\begin{array}{l}\text { Disease, } \\
\text { conditions }\end{array}$ & Study & Study design & Subjects characteristics & Main results \\
\hline \multirow[t]{4}{*}{ Bronchiolitis } & $\begin{array}{l}\text { Kepreotes, }^{12)} \\
2017\end{array}$ & $\begin{array}{l}\text { RCT, high flow (1 L/min } / \mathrm{kg}) \text { vs. } \\
\text { standard flow }(2 \mathrm{~L} / \mathrm{min})\end{array}$ & $\begin{array}{l}\mathrm{N}=202,<24 \text { months, moderate } \\
\text { bronchiolitis }\end{array}$ & $\begin{array}{l}\text { - Lower rate of treatment failure in HFNC group } \\
\text { - No differences in duration of oxygen therapy and ICU } \\
\text { transfer }\end{array}$ \\
\hline & $\begin{array}{l}\text { Franklin, }^{13)} \\
2018\end{array}$ & $\begin{array}{l}\text { RCT, high flow }(2 \mathrm{~L} / \mathrm{min} / \mathrm{kg}) \mathrm{vs} \text {. } \\
\text { standard flow }(2 \mathrm{~L} / \mathrm{min})\end{array}$ & $\begin{array}{l}\mathrm{N}=1,472,<12 \text { months, mode- } \\
\text { rate bronchiolitis }\end{array}$ & $\begin{array}{l}\text { - Lower rate of treatment failure in HFNC group } \\
\text { - No differences in duration of oxygen therapy, } \\
\text { hospital stay, and ICU transfer }\end{array}$ \\
\hline & $\begin{array}{c}\text { Milesi, }^{14)} \\
2018\end{array}$ & $\begin{array}{l}\text { RCT, high flow }(2 \mathrm{~L} / \mathrm{min} / \mathrm{kg}) \text { vs. } \\
\text { high flow }(3 \mathrm{~L} / \mathrm{min} / \mathrm{kg})\end{array}$ & $\begin{array}{l}\mathrm{N}=286,<6 \text { months, moderate } \\
\text { to severe bronchiolitis }\end{array}$ & $\begin{array}{l}\text { - No differences in the rate of treatment failure } \\
\text { - More discomfort in group with } 3 \mathrm{~L} / \mathrm{kg} / \mathrm{min}\end{array}$ \\
\hline & Lin, $^{19)} 2019$ & $\begin{array}{l}\text { Systematic review, } 9 \text { RCTs, } \\
\text { HFNC vs. other oxygen } \\
\text { therapies (SOT, nCPAP) }\end{array}$ & $N=2,121$ & $\begin{array}{l}\text { vs. SOT and nCPAP } \\
\text { - No differences in length of stay, duration of oxygen } \\
\text { therapy, ICU transfer, intubation rate, respiratory } \\
\text { rate, } \mathrm{SpO} 2 \text { and adverse events } \\
\text { - Significant reduction of the treatment failure (RR, } \\
\text { 0.50; } 95 \% \mathrm{Cl}, 0.40-0.62 \text { ) compared with SOT group } \\
\text { - Significant increase of the treatment failure (RR, } \\
1.61 ; 95 \% \mathrm{Cl}, 1.06-2.42) \text { compared with nCPAP } \\
\text { group } \\
\text { - Significant decreased of length of stay compared } \\
\text { with SOT group in low-income and middle-income } \\
\text { countries }\end{array}$ \\
\hline \multirow[t]{2}{*}{ Asthma } & $\begin{array}{l}\text { Baudin, } \\
2017\end{array}$ & $\begin{array}{l}\text { Retrospective observational } \\
\text { study, HFNC vs. SOT }\end{array}$ & $\begin{array}{l}\mathrm{N}=73,1-18 \text { years, ICU patients } \\
\text { with status asthmaticus }\end{array}$ & $\begin{array}{l}\text { - Improvement in } \mathrm{pH}, \mathrm{pCO} \text {, heart rate, respiration } \\
\text { rate, and oxygenation in HFNC group compared to } \\
\text { SOT group }\end{array}$ \\
\hline & $\begin{array}{l}\text { Ballestero, } \\
2018\end{array}$ & $\begin{array}{l}\text { Prospective randomized pilot } \\
\text { trial, HFNC vs. SOT }\end{array}$ & $\begin{array}{l}\mathrm{N}=62,1-14 \text { years, ED patients } \\
\text { with moderate-to-severe } \\
\text { asthma exacerbation }\end{array}$ & $\begin{array}{l}\text { - At } 2 \text { hours after the start of therapy, improvement } \\
\text { in pulmonary score in HFNC group compared to SOT } \\
\text { group }\end{array}$ \\
\hline \multirow{2}{*}{$\begin{array}{l}\text { Obstructive } \\
\text { apnea/ } \\
\text { hypopnea }\end{array}$} & $\begin{array}{l}\text { Hawkins, } \\
2017\end{array}$ & $\begin{array}{l}\text { Observational study, HFNC } \\
10-50 \mathrm{~L} / \mathrm{min}\end{array}$ & $\begin{array}{l}\mathrm{N}=10,1-18 \text { years old, OSAS and } \\
\text { CPAP intolerance }\end{array}$ & $\begin{array}{l}\text { - Improvement in obstructive apnea-hypopnea index, } \\
\text { SpO2, and heart rate in CPAP-intolerant children }\end{array}$ \\
\hline & $\begin{array}{l}\text { Joseph, } \\
2015\end{array}$ & Retrospective review & $\begin{array}{l}\mathrm{N}=5,2 \text { months }-15 \text { years, OSAS } \\
\text { and CPAP intolerance }\end{array}$ & $\begin{array}{l}\text { - Improvement in apnea-hypopnea index and nadir } \\
\text { oxygen saturation }\end{array}$ \\
\hline \multirow[t]{2}{*}{ Postextubation } & $\begin{array}{l}\text { Shioji, } \\
2017\end{array}$ & $\begin{array}{l}\text { Retrospective observational } \\
\text { study, pre-HFNC vs. post- } \\
\text { HFNC }\end{array}$ & $\begin{array}{l}\mathrm{N}=20,<48 \text { months, postex- } \\
\text { tubation respiratory failure } \\
\text { after cardiac surgery }\end{array}$ & - Improvement in respiration rate after HFNC apply \\
\hline & $\begin{array}{l}\text { Akyıldız, } \\
2018\end{array}$ & $\begin{array}{l}\text { RCT, HFNC vs. conventional } \\
\text { oxygen therapy }\end{array}$ & $\begin{array}{l}\mathrm{N}=100,1 \text { month- } 18 \text { years, ICU } \\
\text { patients after extubation }\end{array}$ & $\begin{array}{l}\text { - Improvement in respiration rate, heart rate, end-tidal } \\
\mathrm{CO} 2 \text {, and atelectasis in HFNC group } \\
\text { - Lower failure rate of extubation in HFNC group }\end{array}$ \\
\hline Pneumonia & $\begin{array}{c}\text { Chisti, } \\
2015\end{array}$ & $\begin{array}{l}\text { Open RCT, HFNC vs. bubble } \\
\text { CPAP vs. low-flow oxygen }\end{array}$ & $\begin{array}{l}\mathrm{N}=225,<5 \text { years old, severe } \\
\text { pneumonia and hypoxemia }\end{array}$ & $\begin{array}{l}\text { - No difference in the treatment failure after more } \\
\text { than } 1 \text { hour of treatment between children with } \\
\text { HFNC and bubble CPAP } \\
\text { - Study was early stopped because of higher mortality } \\
\text { in the low-flow oxygen group }\end{array}$ \\
\hline $\begin{array}{l}\text { Respiratory } \\
\text { distress }\end{array}$ & $\begin{array}{l}\text { Vitaliti, }^{30)} \\
2017\end{array}$ & $\begin{array}{l}\text { Prospective observational } \\
\text { study, HFNC vs. helmet CPAP }\end{array}$ & $\begin{array}{l}\mathrm{N}=60,1-24 \text { months, bronchio- } \\
\text { litis }(n=31) \text {, pneumoni a }(n=7) \text {, } \\
\text { asthma }(n=2)\end{array}$ & $\begin{array}{l}\text { - Improvement of respiratory distress both HFNC and } \\
\text { helmet CPAP group, but helmet CPAP was more } \\
\text { efficient and rapid compared with HFNC }\end{array}$ \\
\hline
\end{tabular}

RCT, randomized controlled trial; HFNC, high-flow nasal cannula; ICU, intensive care unit; SOT, standard oxygen therapy; nCPAP, nasal continuous positive airway pressure; $\mathrm{Cl}$, confidence interval; ED, Emergency Department; RR, risk ratio; OSAS, obstructive sleep apnea syndrome.

randomized pilot trial of Emergency Department (ED) patients with moderate to severe asthma exacerbation reported an improved pulmonary score in the HFNC group versus the standard oxygen group at 2 hours after treatment. ${ }^{21)}$ When using HFNC to treat asthma, physicians must consider optimal inhalation therapies such as a bronchodilator, anticholinergic agents, and inhaled corticosteroids. Because HFNC can reduce the entrainment of ambient air, it inhibits optimal inhalation therapy via a nebulizer. Current evidence reported that the amount of aerosol delivery was meager in an in vitro high-flow system. ${ }^{22)}$ In this situation, temporary discontinuation of HFNC or lowering the flow to $<5 \mathrm{~L} / \mathrm{min}$ should be considered at the time of nebulization.

\section{Other indications}

Clinical indications reported from 67 pediatric ICU (PICU) and neonatal ICU in Germany included bronchiolitis, respiratory support for preterm infants, pneumonia, severe obstructive bronchitis or asthma, bridging to intubation, and postextubation support. ${ }^{16)}$ Apnea, postoperative respiratory support, and upper airway obstruction were also reported, but evidence-based studies are lacking. In the ED, HFNC could be considered for 
patients with respiratory distress not requiring immediate endotracheal intubation. ${ }^{23)}$

In adult studies of acute respiratory failure, HFNC reduced the rates of intubation, mechanical ventilation, and escalation of respiratory support compared to conventional oxygen therapy but showed no better outcomes than noninvasive ventilation. ${ }^{24)}$ Acute respiratory failure due to various etiology in children might be treated with HFNC before other respiratory supports according to patient severity and clinical settings. HFNC improved oxygenation by reducing HR in CPAP-intolerant children $(\mathrm{N}=10)$ with obstructive sleep apnea syndrome (OSAS). ${ }^{25)}$ Moreover, another study reported improvements in the apneahypopnea index and nadir oxygen saturation in 5 patients with HFNC. ${ }^{26)}$ These studies suggested that HFNC could warrant further studies and consideration as alternative OSAS therapies. HFNC therapy improved the respiration rate of pediatric patients with postextubation acute respiratory failure after cardiac surgery. ${ }^{27)}$ HFNC showed a lower failure rate after extubation compared with that of the conventional oxygen therapy group in the ICU. ${ }^{28)}$

Studies comparing the efficacy and safety of NRSs are rare. One RCT comparing low-flow oxygen, HFNC, and bubble CPAP for children with severe pneumonia and hypoxemia reported no difference in the treatment failure rate after more than 1 hour of treatment between children supported by HFNC and those with bubble CPAP. ${ }^{29)}$ This study was stopped early because of the higher mortality rate in the low-flow oxygen group. Although there was no statistical significance in mortality between the HFNC $(10$ of $79,13 \%)$ and bubble CPAP (3 of $79,4 \%)$ groups, careful interpretation is needed due to flow limitations of HFNC $(2 \mathrm{~L} / \mathrm{kg} / \mathrm{min}$ up to the maximum of $12 \mathrm{~L} /$ $\mathrm{min}$ ) in subjects younger than 5 years. Another study comparing HFNC and helmet CPAP in children with respiratory distress aged 1-24 months reported that both improved respiratory distress, although the clinical response to helmet CPAP was more efficient and rapid than that to HFNC. ${ }^{30)}$ In 2017, a randomized feasibility trial of NRS including HFNC and CPAP was conducted in critically ill children with primary respiratory failure (group A: step-up NRS) and postextubation support (group B: step-down NRS). This pilot study showed that it was feasible to conduct a large RCT in the pediatric critical care setting. ${ }^{31)}$

\section{Identification of efficacy}

Good responders to HFNC generally show improvements in RR, HR, and work of breathing (WOB) within the first 60-90 minutes. ${ }^{17)}$ Reductions in apnea and oxygen requirements are also indicative. If the patients showed an increasing oxygen requirement and unchanged or increasing $\mathrm{RR}, \mathrm{HR}$, and $\mathrm{WOB}$ in this period, adjustment of flow rate and $\mathrm{FiO}_{2}$, another respiratory support and ICU transfer from the ward should be considered. Nonresponders in severe viral bronchiolitis were more likely to have a higher pediatric risk of mortality III scores (PRISM III). ${ }^{32)}$ Therefore, careful observation with a pulse oximeter using a central monitoring system is important for the early detection of aggravation.

\section{Safety issue in children}

HFNC is generally safe in the general pediatric ward, ED, and PICU. A well-known complication of HFNC is barotrauma such as air-trapping, pneumothorax, and pneumomediastinum. Serious pneumothorax in children has been infrequently reported. ${ }^{33)}$ Careful observation seems mandatory since this was reported even in a low-flow condition $(6 \mathrm{~L} / \mathrm{min}$ in 22 -month-old child). The use of an inappropriately large cannula is associated with barotrauma. Abdominal distention and nasal mucosal injury can also occur. Nonadherence to HFNC is sometimes reported in children. ${ }^{22)}$

\section{Conclusion}

A comparison of clinical outcomes between the pre- and postHFNC eras was conducted in a PICU. ${ }^{34)}$ Significant decreases in intubation rate and total mechanical ventilator days per admission were reported despite no associated changes in mortality. Strong evidence exists for rescue therapy for acute bronchiolitis, while advantages of other indications have been reported. Better designed and controlled studies are needed for other indications and comparisons with other respiratory supports. Although HFNC is a relatively safe, well-tolerated, and feasible method in a general pediatric ward, ED, or ICU, careful monitoring is required to detect nonresponders and potential complications.

\section{Conflicts of interest}

No potential conflict of interest relevant to this article was reported.

\section{References}

1. Drake MG. High-flow nasal cannula oxygen in adults: an evidence-based assessment. Ann Am Thorac Soc 2018;15:145-55.

2. Jeon GW. Respiratory support with heated humidified high flow nasal cannula in preterm infants. Korean J Pediatr 2016;59:389-94.

3. Möller W, Feng S, Domanski U, Franke KJ, Celik G, Bartenstein P, et al. Nasal high flow reduces dead space. J Appl Physiol (1985) 2017;122:191-7.

4. Rubin S, Ghuman A, Deakers T, Khemani R, Ross P, Newth CJ. Effort of breathing in children receiving high-flow nasal cannula. Pediatr Crit Care Med 2014;15:1-6.

5. Spoletini G, Alotaibi M, Blasi F, Hill NS. Heated humidified high-flow nasal oxygen in adults: mechanisms of action and clinical implications. Chest 2015;148:253-61.

6. Goligher EC, Slutsky AS. Not Just Oxygen? Mechanisms of benefit from highflow nasal cannula in hypoxemic respiratory failure. Am J Respir Crit Care Med 2017;195:1128-31.

7. Sivieri EM, Gerdes JS, Abbasi S. Effect of HFNC flow rate, cannula size, 
and nares diameter on generated airway pressures: an in vitro study. Pediatr Pulmonol 2013;48:506-14.

8. Hasan RA, Habib RH. Effects of flow rate and airleak at the nares and mouth opening on positive distending pressure delivery using commercially available high-flow nasal cannula systems: a lung model study. Pediatr Crit Care Med 2011;12:e29-33.

9. Arora B, Mahajan P, Zidan MA, Sethuraman U. Nasopharyngeal airway pressures in bronchiolitis patients treated with high-flow nasal cannula oxygen therapy. Pediatr Emerg Care 2012;28:1179-84.

10. Braunlich J, Beyer D, Mai D, Hammerschmidt S, Seyfarth HJ, Wirtz H. Effects of nasal high flow on ventilation in volunteers, COPD and idiopathic pulmonary fibrosis patients. Respiration 2013;85:319-25.

11. Milesi C, Baleine J, Matecki S, Durand S, Combes C, Novais AR, et al. Is treatment with a high flow nasal cannula effective in acute viral bronchiolitis? A physiologic study. Intensive Care Med 2013;39:1088-94.

12. Kepreotes E, Whitehead B, Attia J, Oldmeadow C, Collison A, Searles A, et al. High-flow warm humidified oxygen versus standard low-flow nasal cannula oxygen for moderate bronchiolitis (HFWHO RCT): an open, phase 4, randomised controlled trial. Lancet 2017;389:930-9.

13. Franklin D, Babl FE, Schlapbach LJ, Oakley E, Craig S, Neutze J, et al. A randomized trial of high-flow oxygen therapy in infants with bronchiolitis. $\mathrm{N}$ Engl J Med 2018;378:1121-31.

14. Milesi C, Pierre AF, Deho A, Pouyau R, Liet JM, Guillot C, et al. A multicenter randomized controlled trial of a $3-\mathrm{L} / \mathrm{kg} / \mathrm{min}$ versus $2-\mathrm{L} / \mathrm{kg} / \mathrm{min}$ high-flow nasal cannula flow rate in young infants with severe viral bronchiolitis (TRAMONTANE 2). Intensive Care Med 2018;44:1870-8.

15. Milesi C, Essouri S, Pouyau R, Liet JM, Afanetti M, Portefaix A, et al. High flow nasal cannula (HFNC) versus nasal continuous positive airway pressure (nCPAP) for the initial respiratory management of acute viral bronchiolitis in young infants: a multicenter randomized controlled trial (TRAMONTANE study). Intensive Care Med 2017;43:209-16.

16. Schmid F, Olbertz DM, Ballmann M. The use of high-flow nasal cannula (HFNC) as respiratory support in neonatal and pediatric intensive care units in Germany - A nationwide survey. Respir Med 2017;131:210-4.

17. Lodeserto FJ, Lettich TM, Rezaie SR. High-flow nasal cannula: mechanisms of action and adult and pediatric indications. Cureus 2018;10: e3639.

18. Mikalsen IB, Davis P, Øymar K. High flow nasal cannula in children: a literature review. Scand J Trauma Resusc Emerg Med 2016;24:93.

19. Lin J, Zhang Y, Xiong L, Liu S, Gong C, Dai J. High-flow nasal cannula therapy for children with bronchiolitis: a systematic review and meta-analysis. Arch Dis Child 2019;104:564-76.

20. Baudin F, Buisson A, Vanel B, Massenavette B, Pouyau R, Javouhey E. Nasal high flow in management of children with status asthmaticus: a retrospective observational study. Ann Intensive Care 2017;7:55.
21. Ballestero Y, De Pedro J, Portillo N, Martinez-Mugica O, Arana-Arri E, Benito J. Pilot clinical trial of high-flow oxygen therapy in children with asthma in the emergency service. J Pediatr 2018;194:204-10.e3.

22. Al-Subu AM, Hagen S, Eldridge M, Boriosi J. Aerosol therapy through high flow nasal cannula in pediatric patients. Expert Rev Respir Med 2017; 11:94553.

23. Slain KN, Shein SL, Rotta AT. The use of high-flow nasal cannula in the pediatric emergency department. J Pediatr (Rio J) 2017;93 Suppl 1:36-45.

24. Zhao H, Wang H, Sun F, Lyu S, An Y. High-flow nasal cannula oxygen therapy is superior to conventional oxygen therapy but not to noninvasive mechanical ventilation on intubation rate: a systematic review and meta-analysis. Crit Care 2017;21:184

25. Hawkins S, Huston S, Campbell K, Halbower A. High-flow, heated, humidified air via nasal cannula treats CPAP-intolerant children with obstructive sleep apnea. J Clin Sleep Med 2017;13:981-9.

26. Joseph L, Goldberg S, Shitrit M, Picard E. High-flow nasal cannula therapy for obstructive sleep apnea in children. J Clin Sleep Med 2015; 11:1007-10.

27. Shioji N, Iwasaki T, Kanazawa T, Shimizu K, Suemori T, Sugimoto K, et al. Physiological impact of high-flow nasal cannula therapy on postextubation acute respiratory failure after pediatric cardiac surgery: a prospective observational study. J Intensive Care 2017;5:35.

28. Akyıldız B, Özturk S, Ülgen-Tekerek N, Doğanay S, Görkem SB. Comparison between high-flow nasal oxygen cannula and conventional oxygen therapy after extubation in pediatric intensive care unit. Turk J Pediatr 2018;60:12633.

29. Chisti MJ, Salam MA, Smith JH, Ahmed T, Pietroni MA, Shahunja KM, et al. Bubble continuous positive airway pressure for children with severe pneumonia and hypoxaemia in Bangladesh: an open, randomised controlled trial. Lancet 2015;386:1057-65.

30. Vitaliti G, Vitaliti MC, Finocchiaro MC, Di Stefano VA, Pavone P, Matin N, et al. Randomized comparison of helmet CPAP versus high-flow nasal cannula oxygen in pediatric respiratory distress. Respir Care 2017; 62:1036-42.

31. Ramnarayan P, Lister P, Dominguez T, Habibi P, Edmonds N, Canter RR, et al. FIRST-line support for Assistance in Breathing in Children (FIRST-ABC): a multicentre pilot randomised controlled trial of high-flow nasal cannula therapy versus continuous positive airway pressure in paediatric critical care. Crit Care 2018;22:144.

32. Abboud PA, Roth PJ, Skiles CL, Stolfi A, Rowin ME. Predictors of failure in infants with viral bronchiolitis treated with high-flow, high-humidity nasal cannula therapy*. Pediatr Crit Care Med 2012;13:e343-9.

33. Hegde S, Prodhan P. Serious air leak syndrome complicating high-flow nasal cannula therapy: a report of 3 cases. Pediatrics 2013;131:e939-44.

34. Kawaguchi A, Yasui Y, deCaen A, Garros D. The clinical impact of heated humidified high-flow nasal cannula on pediatric respiratory distress. Pediatr Crit Care Med 2017;18:112-9. 